\title{
Association of Americium-241 with Adenochromes in the Branchial Hearts of the Cephalopod Octopus vulgaris
}

\author{
P. Miramand* and J. C. Guary
}

International Laboratory of Marine Radioactivity, LAEA, Musée Océanographique, Principality of Monaco

ABSTRACT: An autoradiographic study of the subcellular localization of ${ }^{241} \mathrm{Am}$ in the branchial hearts of the cephalopod Octopus vulgaris was carried out after uptake from sea water. It was demonstrated that the radionuclide is closely associated with granular pigment concretions or adenochromes occurring in the cells of the branchial hearts of the octopus.

The branchial hearts of the molluscan cephalopod Octopus vulgaris can concentrate certain transuranium elements $\left({ }^{241} \mathrm{Am},{ }^{239+240} \mathrm{Pu}\right)$ and natural nuclides $\left({ }^{232} \mathrm{Th}\right.$, ${ }^{210} \mathrm{Po},{ }^{210} \mathrm{~Pb}$ ) very effectively (Guary et al., 1981). In particular, these very small organs, which possess circulatory and excretory functions (Cuénot, 1899; Turchini, 1923; Martin and Harrison, 1966), concentrate the ${ }^{241} \mathrm{Am}$ present in sea water from atmospheric fallout to a level of about $40 \mathrm{mBq} \mathrm{kg} \mathrm{kg}^{-1}\left(1 \mathrm{pCi} \mathrm{kg}^{-1}\right)$ wet weight; the concentration factors of ${ }^{241} \mathrm{Am}$ with respect to sea water in the branchial hearts, as well as those of ${ }^{239+240} \mathrm{Pu},{ }^{232} \mathrm{Th},{ }^{210} \mathrm{Po}$ and ${ }^{210} \mathrm{~Pb}$, are as high as $10^{4}$ (Guary et al., 1981). Moreover, it has been demonstrated that these organs are able to accumulate vanadium (Miramand and Guary, 1980) and cobalt (Nakahara et al., 1979) with concentration factors of $3 \times 10^{3}$ and $2 \times 10^{4}$, respectively. These data suggest that the branchial hearts of the octopus have considerable potential as monitors of transuranics, and probably certain other elements, in the marine environment. It is accordingly important that the physiology of the branchial hearts be understood and that the intracellular sites of binding of radionuclides in these organs be established.

An Octopus vulgaris female (360 g) was caught in the littoral zone off Monaco and placed in filtered and aerated sea water at $13^{\circ} \pm 1 \mathrm{C}^{\circ}$. The sea water (4 l) had been spiked previously with ${ }^{241} \mathrm{Am}$ (assumed to be in +3 state) at a concentration of $1 \mathrm{kBq} \mathrm{l}^{-1}\left(30 \mathrm{nCi} \mathrm{l}^{-1}\right)$. Throughout the 10-d exposure period, the spiked sea

\footnotetext{
- Present address: Laboratorire de Radioécologie Marine, DPr, Commissariat à l'Energie Atomique, Centre de La Hague, B.P. 270, Cherbourg 50107, France
}

water was changed every other day in order to maintain the radiotracer concentration relatively constant. The test animal was then transferred to a $100 \mathrm{l}$ tank supplied with flowing sea water, and fed daily with crabs for 70- $d$ in an attempt to ensure a high degree of redistribution of the radionuclide between the different organs. During these two phases the cephalopod was monitored regularly by gamma-spectrometry using a 3" NaI (Tl) crystal. After the 70-d period, the cephalopod (by now weighing $680 \mathrm{~g}$ ) was dissected. Branchial hearts were removed immediately from the living cephalopod, and several small pieces were fixed in Bouin's solution and gamma-counted at the same time as the other tissues and organs. It was particularly noteworthy that branchial hearts, which account for only $0.2 \%$ of the body weight, contained $99 \%$ of the total radioactive body burden. Further details concerning the uptake, loss and distribution of the radionuclide have been published (Guary, 1980)., The concentration of activity in the branchial hearts was about 4

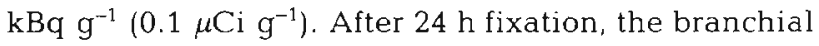
hearts were dehydrated and embedded in paraffin and sectioned at $5 \mu \mathrm{m}$. Sections were collected on glass slides, dried and dewaxed. Autoradiographs were prepared with Ilford $\mathrm{K} 2$ nuclear emulsion (diluted with $1 \%$ glycerin solution at $43^{\circ} \mathrm{C}$ ) by the dipping technique (Rogers, 1973). Emulsion-coated slides were dehydrated and exposed for $15 \mathrm{~d}$ in light-proof boxes at $4{ }^{\circ} \mathrm{C}$. Exposed autoradiographs were developed, fixed and washed, and then stained with haemalum-eosin. The stained slides were dehydrated and mounted for microscopic examination.

In the autoradiographs prepared from branchial hearts, one can easily see the abundance of the naturally-occurring intracellular granules (Fig. 1). In the enlargement (Fig. 2) numerous stars composed of many alpha-tracks emerging from the dark spots show clearly that ${ }^{241} \mathrm{Am}$ is associated with the granules in the cells of the branchial hearts.

The granules localized in the polyhedral cells are, in fact, made of purple brown pigments called adeno- 


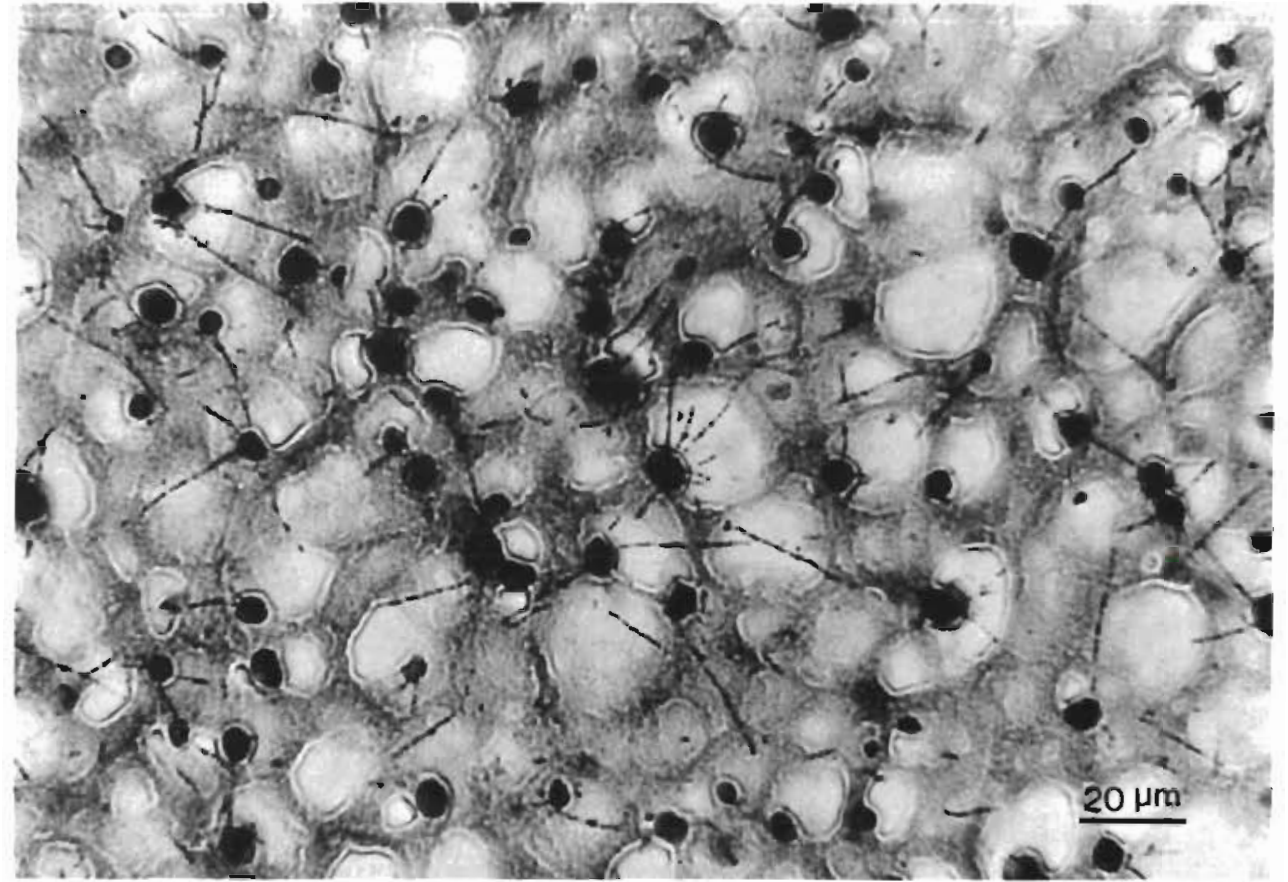

Fig. 1 Octopus vulgaris. Autoradiograph of branchial hearts from an individual labelled with ${ }^{241}$ Am. General view of cells with numerous intracellular granules or adenochromes chromes (Fox and Updegraff, 1943). Such intracellular pigment concretions were first reported by Cuénot et al. (1908) and are generally considered as metabolic waste products (Cuénot et al., 1908; Turchini, 1923; Fox and Updegraff, 1943). More recently, adenochromes have been isolated from the branchial hearts of the octopus (Nardi and Steinberg, 1974) and their chemical structure well established (Ito et al., 1976). This iron (III)-containing pigment is found in large amounts (12 $\mathrm{mg} \mathrm{g}^{-1}$ wet weight) in branchial hearts
(Palumbo et al., 1977) but occurs also in gills, branchial glands, ovaries, hepatopancreas, kidneys, white bodies and amoebocytes (Nardi and Steinberg, 1974; Palumbo et al., 1977). The iron content of the branchial hearts ranges typically between 0.1 and $0.3 \%$ of dry weight (Nardi and Steinberg, 1974). Interestingly, these authors have suggested that adenochromes, which have a high affinity for iron, can behave as natural complexing agents. It is thus possible to explain their close association with various heavy metals

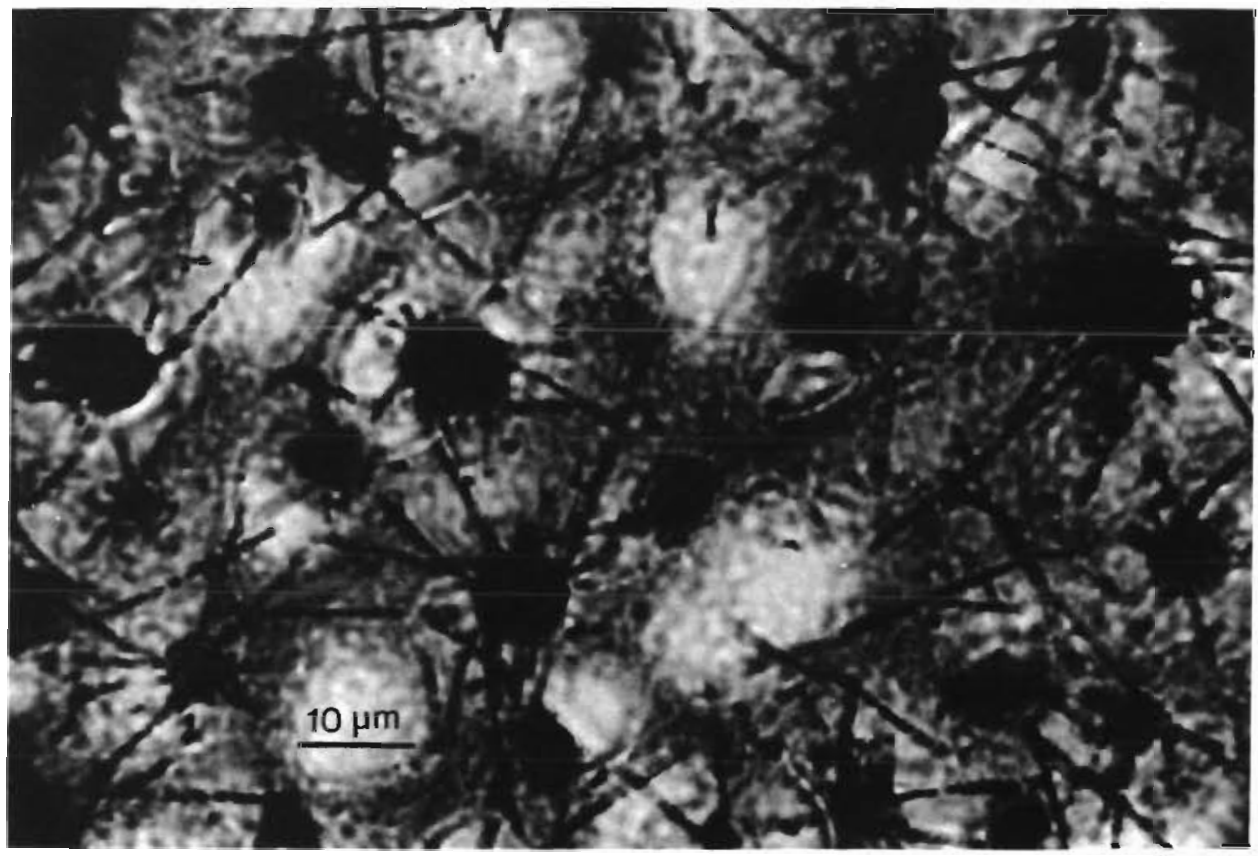

Fig. 2. Octopus vulgaris. Enlargement of Figure 1 showing detalls of the association of ${ }^{241} \mathrm{Am}$ with adenochromes 
such as, in the present case, americium. As we have already noted (Guary et al., 1981), adenochromes in Octopus are probably engaged in a detoxification process of heavy metal which is comparable to that described for other molluscs (Coombs, 1977; Martoja et al., 1977; Coombs and George, 1978). These elements could have been transported into the cells of branchial hearts to the pigment concretions by micropinocytosis as suggested by the numerous micropinocytotical vesicles observed in these organs (Guary, 1980) and by the study of ferritin transport in the branchial hearts of Sepia officinalis (Schipp and Hevert, 1978). Extension of the autoradiographic approach to electron microscopy may be useful in helping to elucidate the exact process by which americium particles are deposited and translocated at the subcellular level.

Acknowledgements. The International Laboratory of Marine Radioactivity operates under a tripartite agreement between the International Atomic Energy Agency, the Government of the Principality of Monaco and the Oceanographic Institute at Monaco. We thank Drs. R. D. Cherry and S. W. Fowler for critical comments.

\section{LITERATURE CITED}

Coombs, T. L. (1977). Uptake and storage mechanisms of heavy metals in marine organisms. Proc. Analyt. Div. Chem. Soc. 14: 219-222

Coombs, T. L., George, S. G. (1978). Mechanisms of immobilization and detoxication of metals in marine organisms. In: Mc Lusky, D. S., Berry, A. J. (eds) Physiology and behaviour of marine organisms. Pergamon Press, Oxford, pp. $179-187$

Cuénot, K. (1899). L'excrétion chez les Mollusques. Archs Biol., Paris 16: 49-96

Cuénot, K., Gonet, V., Bruntz, L. (1908). Recherches chimiques sur les coeurs branchiaux des Céphalopodes. Démonstration du rôle excréteur des cellules qui éliminent le carmin ammoniacal des injections physiologiques. Archs Zool. exp. gén. 9. Notes et Revue 3: 49-53
Fox, D. L., Updegraff, D. M. (1943). Adenochrome, a glandular pigment in the branchial hearts of the octopus. Archs Biochem. 1: 339-356

Guary, J. C. (1980). Recherches sur les transferts et la fixation du plutonium, de l'américium et du neptunium dans le milieu marin. Thèse de Doctorat d'Etat (Sciences), Université d'Aix-Marseille II

Guary, J.-C., Higgo, J. J. W., Cherry, R. D., Heyraud, M. (1981). High concentrations of transuranics and natural radioactive elements in the branchral hearts of the cephalopod Octopus vulgaris. Mar Ecol. Prog. Ser 4: $123-126$

Ito, S., Nardi, G., Prota, G. (1976). Structures of adenochromines $A$ and $B$, the iron (III) binding amino-acids of $a$ unique group of peptides, adenochromes from Octopus vulgaris. J. chem. Soc., Chem. Communs 24: 1042-1043

Martin, A. W., Harrison, F. M. (1966). Excretion. In: Wilbur, K. M., Yonge, C. M. (eds) Physiology of mollusca, Vol. II. Academic Press, New York, pp. 353-386

Martoja, M., Lhonoré, J., Elkaim, B. (1977). Accumulations de métaux et de particules minérales dans les tissus mous de la coque comestible Cerastoderma edule (Mollusque Eulamellibranche). Relation avec le milieu. C. I. hebd. Séanc. Acad. Scí, Paris 284 D: 1453-1456

Miramand, P., Guary, J. C. (1980). High concentrations of some heavy metals in tissues of the Mediterranean octopus. Bull. environ. Contam. Toxicol. 24: 783-788

Nakahara, M., Koyonagi, T., Ueda, T., Shimizu, C. (1979). Peculiar accumulation of cobalt -60 by the branchial heart of octopus. Bull. Japan. Soc. scient. Fish. 45: 539

Nardi, G., Steinberg, H. (1974). Isolation and distribution of adenochrome(s) in Octopus vulgaris. Comp. Biochem. Physiol. 48 B: 453-461

Palumbo, A., Ito, S., Nardi, G., Prota, G. (1977). Isolation of a possible biosynthetic precursor of adenochrome from the white bodies of Octopus vulgaris. Comp. Biochem. Physiol. 58 B: $353-356$

Rogers, A. W. (1973). Techniques of autoradiography, Elsevier, Amsterdam

Schipp, R., Hevert, F. (1978). Distribution of copper and iron in some central organs of Sepia officinalis (Cephalopoda). A comparative study by flameless atomic absorption and electron microscopy. Mar. Biol. 47: 391-399

Turchini, J. (1923). Contribution à l'etude de l'histologie de la cellule rénale. L'excrêtion urinaire chez les Mollusques. Archs Morph. gén. exp. 18: 7-241 